\title{
Irfani
}

ISSN 1907-0969 E ISSN 2442-8272

Volume 16 Nomor 1 Juni 2020

Halaman 69-81

http://journal.iaingorontalo.ac.id/index.php/ir

\section{PENDIDIKAN KARAKTER BERBASIS AKHLAQ}

\author{
Saifulhaq Inaku ${ }^{1}$, Muhammad Nur Iman ${ }^{2}$ \\ ${ }^{12}$ IAIN Sultan Amai Gorontalo \\ email: saiful.inaku@gmail.com
}

\begin{abstract}
ABSTRAK
Pendidikan karakter adalah amanat Pancasila dan UUD 1945, sehingga pemerintah menjadikan pembangunan karakter sebagai salah satu program prioritas pembangunan nasional. Telah banyak konsep pendidikan karakter yang ditawarkan dalam dunia pendidikan, namun yang menjadi perhatian penulis adalah Pendidikan Karakter Berbasis Akhlak. Penelitian ini adalah penelitian studi dokumen yang kajiannya menitikberatkan pada analisis atau interpretasi bahan tertulis berdasarkan konteksnya. Bahannya berupa catatan yang terpublikasikan, buku teks, surat kabar, naskah, artikel, dan sejenisnya. Hasil penelitian menunjukkan bahwa Pendidikan Karakter Berbasis Akhlak mengarah pada penciptaan karakter peserta didik yang ahli ibadah, memiliki nilai-nilai akhlak, yaitu akhlak kepada Tuhan, akhlak kepada kedua orang tua, akhlak kepada guru, akhlak kepada sesama, menjadi warga negara yang baik, melakukan amal perbuatan yang bermaslahat bagi semua umat manusia. Artikel ini tentu memiliki kekurangan, oleh karena itu kritik dan saran yang konstruktif sangat diharapkan demi kesempurnaannya.
\end{abstract}

Kata Kunci: Pendidikan, Karakter, Akhlaq

\begin{abstract}
Character education is the mandate of the Pancasila and the 1945 Constitution, so that the government makes character development as one of the national development priority programs. There have been many concepts of character education offered in the world of education, but what concerns the author is Character Based Moral Education. This research is a documentary research study whose study focuses on the analysis or interpretation of written materials based on the context. The material is in the form of published notes, textbooks, newspapers, manuscripts, articles, and the like. The results showed that characterbased character education leads to the creation of the character of students who are experts in worship, have moral values, namely morals to God, morals to both parents, morals to teachers, morals to others, to be good citizens, to do good citizenship good deeds for all humanity. This article certainly has shortcomings, therefore constructive criticism and suggestions are expected for its perfection.
\end{abstract}

Keywords: Education, Character, Akhlaq 


\section{Irfani}

ISSN 1907-0969 E ISSN 2442-8272

Volume 16 Nomor 1 Juni 2020

Halaman 69-81

http://journal.iaingorontalo.ac.id/index.php/ir

\section{PENDAHULUAN}

Proses pendidikan harus didukung dengan penanaman nilai-nilai akhlak yang baik agar dapat menghantarkan setiap orang menjadi manusia yang berkualitas dan cerdas baik secara intelektual, emosional maupun spiritual. Pendidikan ibarat seekor burung yang membawa kedua sayapnya yakni ilmu dan akhlak, sayap yang membawa setiap orang terbang untuk menggapai sesuatu yang diharapkan. Jika seekor burung yang ingin terbang tanpa salah satu sayapnya, pasti tidak dapat terbang menggapai sesuatu yang diharapkan dikarenakan kecacatannya. Individu yang berpengetahuan tinggi tanpa dibarengi dengan akhlak mulia menjadikan pendidikan tersebut menjadi cacat, kehilangan etika dan moral di dalam masyarakat, begitu pula dengan akhlaq, akhlaq tanpa dibarengi dengan ilmu tidak akan bisa memilah mana yang baik dan benar, bagaimana berperilaku baik dan apa saja perilaku tidak baik. Oleh karena itu, hal yang penting di dalam dunia pendidikan adalah penanaman ilmu dan akhlak secara berbarengan, agar pendidikan yang dicapai oleh setiap orang akan sangat bermanfaat untuk dirinya dan orang lain.

Dewasa ini pemerintah telah mencanangkan pendidikan karakter dalam dunia pendidikan yang bertujuan untuk menghasilkan peserta didik yang berakhlak mulia, sehat, berilmu, cakap, kreatif, mandiri, demokratis, dan bertanggung jawab. Namun tidak bisa dipungkiri bahwa hal tersebut belum membuahkan hasi yang maksimal. Karakter generasi muda masih berada pada titik yang sangat mengkhawatirkan. Berdasarkan hasil penelitian yang dilakukan oleh Lembaga Studi Cinta dan Kemanusiaan serta Pelatihan Bisnis dan Humaniora (LSCK PUSBIH), dengan melibatkan 1.666 responden di Kota-kota besar, misalnya; Medan, Jakarta, Bandung, Yogyakarta dan Surabaya. Responden remaja mengaku telah melakukan seks bebas sangat tinggi, bahkan melebihi 50\%. Selain itu, berdasarkan data Pusat Pengendalian Gangguan Sosial DKI Jakarta, pelajar SD, SMP, dan SMA, yang terlibat tawuran mencapai $0,8 \%$ atau sekitar 1.318 siswa (1.645.835), serta korban narkoba 3,9\%. Dan, yang lebih mengejutkan lagi, untuk kota Yogyakarta, sekitar 97,05\%, melakukan seks bebas. Kenyataan tersebut menunjukkan betapa ironisnya kondisi remaja saat ini. ${ }^{1}$

Ada banyak faktor yang mempengaruhi karakter dari setiap orang sehingga menjadi human error, di antaranya adalah pengaruh-pengaruh lingkungan yang tidak begitu memperhatikan pendidikan dan Agama, sehingga begitu banyak peserta didik yang menjadi pembangkang, melawan kepada guru-gurunya di sekolah dan bahkan kepada orang tuanya sekalipun, disebabkan minimnya didikan pengetahuan dan juga keagamaan. Inilah yang menjadi fokus perhatian dalam penelitian ini, yaitu mengungkap bagaimana penerapan pendidikan karakter berbasis akhlak dalam proses pembelajaran. Hal ini penting untuk diketahui agar proses dari pembelajaran itu dapat menjadikan manusia berakhlak mulia dan berpengetahuan agar tujuan dari pendidikan itu sendiri dapat tercapai dengan maksimal. Maka dibuatlah satu penelitian ilmiah dengan tema Pendidikan Karakter Berbasis Akhlak.

1 Uswatun Hasanah, "Model-model Pendidikan Karekter di Sekolah". Al-Tadzkiyyah: Jurnal Pendidikan Islam. Vol. 7, Mei 2016, hal. 19. 


\section{Irfani}

ISSN 1907-0969 E ISSN 2442-8272

Volume 16 Nomor 1 Juni 2020

Halaman 69-81

http://journal.iaingorontalo.ac.id/index.php/ir

\section{PENGERTIAN PENDIDIKAN}

Secara etimologi, pendidikan pada mulanya berasal dari bahasa Yunani yaitu "paedagogie" yang asal katanya paedagogia yang berarti "pergulatan dengan anak". Paduan katanya paedagogos yang berarti paedos (anak) dan agoge (saya membimbing). Jelaslah bahwa paedagogos menyatakan seseorang yang tugasnya membimbing anak dalam pertumbuhan agar dapat berdiri sendiri. ${ }^{2}$

Sementara secara terminologi, Ki Hajar Dewantara menyatakan bahwa, pendidikan adalah proses menuntun segala kekuatan kodrat yang ada pada anak-anak peserta didik, agar mereka sebagai manusia dan sebagai anggota masyarakat dapat mencapai keselamatan dan kebahagiaan setinggi-tingginya. ${ }^{3}$ Ahmad D. Marimba menjelaskan, Pendidikan adalah bimbingan secara sadar oleh si pendidik terhadap perkembangan jasmani dan rohani menuju terbentuknya kepribadian yang utama. ${ }^{4}$

Dari beberapa pengertian di atas dapat dipahami bahwa pendidikan adalah suatu kegiatan yang penting dan suatu kewajiban yang harus dilakukan bagi setiap orang dalam proses membentuk manusia menjadi manusia, dan menjadikan manusia yang berakhlaq, membentuk pribadi-pribadi yang berilmu, membimbing seseorang melakukan kebaikan, menjadikan seseorang menjadi bermanfaat, serta menjadikan seseorang untuk mengenal mana yang baik dan mana yang buruk. Pendidikan akan tidak ada gunanya jika seseorang memiliki ilmu pengetahuan namun hanya digunakan untuk membodohi orang lain dan digunakan untuk hal-hal yang tidak baik demi kepentingan pribadi atau golongan. Jika seperti itu, sama halnya dengan orang yang tidak berpendidikan, bahkan lebih rendah tingkatannya dari orang yang tidak mempunyai pendidikan sama sekali dikarenakan kecacatan pendidikan yang dia miliki.

Dengan adanya proses pendidikan karakter berbasis akhlaq, diharapkan dapat menjadikan setiap orang mempunyai peran penting dalam mengembangkan ilmu pengetahuan demi mewujudkan kepribadian yang utama dan keselamatan bersama serta kebahagiaan yang setinggi-tingginya serta menjadikan setiap orang menjadi rahmatan lil 'ãlamin.

\section{TUJUAN PENDIDIKAN}

Setelah memahami pengertian pendidikan - sebagaimana penjelasan di atas, maka selanjutnya kita akan melihat tujuan dari pendidikan. Menurut Undang-Undang Nomor 20 tahun 2003 tentang Sistem Pendidikan Nasional, pasal 3, disebutkan: Tujuan Pendidikan Nasional adalah mengembangkan potensi peserta didik agar menjadi manusia yang beriman

\footnotetext{
${ }^{2}$ Nik Haryanti, Ilmu Pendidikan Islam, (Malang: Gunung Samudra, 2014), Cet. Ke-1, hlm. 3

3 Chomaidi dan Salamah, Pendidikan dan Pengajaran Strategi Pembelajaran Sekolah, (Jakarta: Grasindo, 2018), hlm. 3

4 Amos Neolaka, Grace Amialia A. Neolaka, Landasan Pendidikan Dasar Pengenalan Diri Sendiri Menuju Perubahan Hidup, (Depok: Kencana, 2017), Cet. Ke-1, hlm. 11
} 


\section{Irfani}

ISSN 1907-0969 E ISSN 2442-8272

Volume 16 Nomor 1 Juni 2020

Halaman 69-81

http://journal.iaingorontalo.ac.id/index.php/ir

dan bertaqwa kepada Tuhan Yang Maha Esa, berakhlak mulia, sehat, berilmu, cakap, kreatif, mandiri, dan menjadi warga negara yang demokratis serta bertanggung jawab. ${ }^{5}$

Di zaman era globalisasi sekarang ini banyak hal yang menjadi faktor terjadinya perubahan perilaku seseorang yang membawanya kepada perilaku tidak berakhlaq, beretika dan bermoral, di antaranya adalah dipengaruhi oleh media yang tidak mendidik dan dipengaruhi lingkungan yang tidak baik. Pendidikan mempunyai tujuan yang jelas, mengantarkan setiap individu di berbagai aspek kehidupan untuk mencapai kedewasaan jasmani dan rohani, serta mengarahkan setiap individu ke arah pribadi yang semakin baik dengan penanaman ilmu-ilmu Agama, sehingga menjadikan pribadi-pribadi yang berilmu dan berakhlak mulia. Betapa pentingnya pendidikan hingga umat muslim diharuskan untuk menuntut ilmu, sebagaimana sabda Nabi saw.:

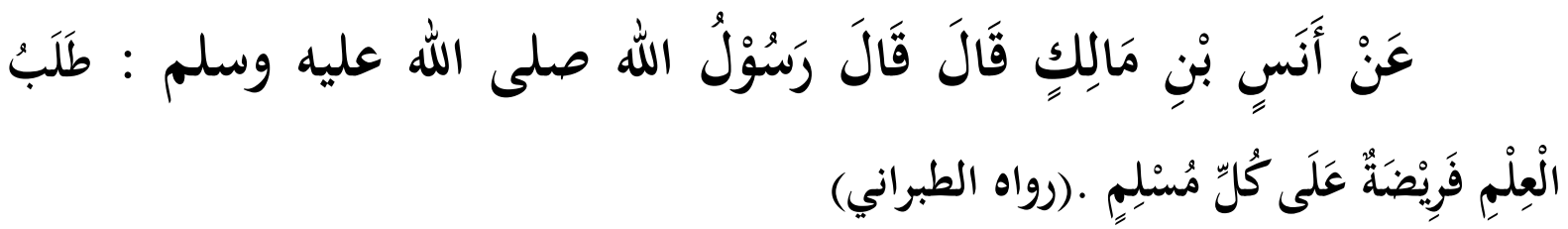

Terjemahnya:

"Dari Anas bin Malik r.a. Menuntut ilmu wajib atas setiap muslim" (HR. at.Thabaranî).

Menuntut ilmu merupakan anjuran Nabi saw. untuk setiap muslim laki-laki dan muslim perempuan agar tidak tersesat dengan kebodohan. Dengan memiliki tujuan pendidikan, kita dapat meramalkan bagaimana hasil akhir usaha-usaha pendidikan yang sekarang ini sedang berlangsung. Ketika kita mampu meramalkan dan memverifikasi kinerja pendidikan, tujuan pendidikan itu lantas menjadi sarana yang dapat semakin mengarahkan guru maupun siswa pada tujuan akhir proses pembelajaran tersebut.

Adanya tujuan ini dapat menentukan sarana-sarana apa saja yang tersedia untuk mencapai tujuan ideal lembaga pendidikan. Ini merupakan tahap-tahap ketika tujuan jangka pendek menjadi penentu keberhasilan tujuan jangka panjang yang sifatnya ideal. Tanpa tujuan yang jelas pendidikan tidak dapat mengevaluasi dirinya sendiri. Tanpa obyek evaluasi, mendidikan tidak dapat menera perkembangan kemajuan yang telah mereka lakukan.

\section{ASAL MUASAL PENDIDIKAN}

Di dalam Agama Islam, pendidikan sudah ada sejak terciptanya manusia pertama kali yaitu nabi Adam a.s.. Dimana Allah swt. menunjuk nabi Adam a.s. untuk menjadi khalifah di muka bumi yang lalu disambut dengan nada tidak setuju oleh para malaikat karena khawatir manusia akan melakukan kerusakan di muka bumi, Sebagaimana firman Allah:

\footnotetext{
${ }^{5}$ Hamid Darmadi, Pengantar Pendidikan Era Globalisasi, (Banten: An1mage, 2019), hlm. 17
} 


\section{Irfani}

ISSN 1907-0969 E ISSN 2442-8272

Volume 16 Nomor 1 Juni 2020

Halaman 69-81

http://journal.iaingorontalo.ac.id/index.php/ir

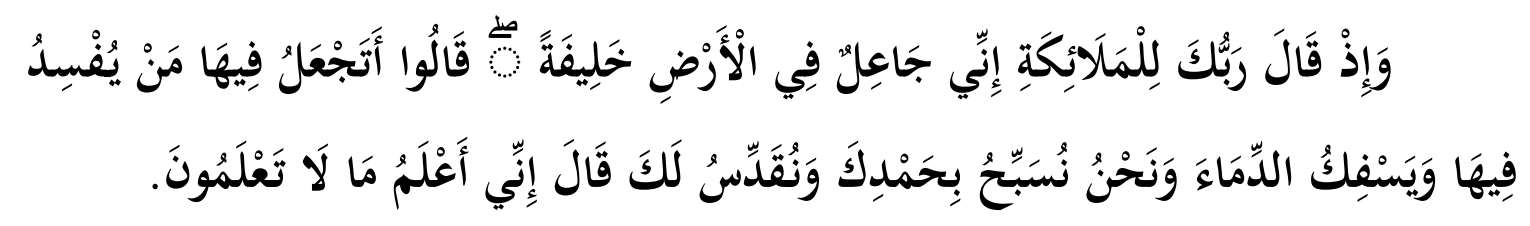

Terjemahnya:

"Dan (ingatlah) ketika Tuhanmu berfirman kepada para malaikat; Sesungguhnya Aku hendak jadikan seorang khalifah di bumi. Mereka bertanya: Apakah Engkau hendak jadikan di bumi orang yang akan membuat bencana dan menumpahkan darah, padahal kami senantiasa bertasbih dengan memuji-Mu dan mengkuduskan Engkau? Tuhan berfirman: Sesungguhnya Aku tahu apa yang kamu tidak tahu”. (QS alBaqarah [2]: 30).

Kemudian Allah mengajarkan nabi Adam a.s. semua nama-nama (benda-benda), bukan saja benda-benda mati akan tetapi seluruh nama-nama dan semua yang telah diciptakan oleh Allah swt., baik yang zhohir maupun yang ghoib.

Sebagaimana Firman Allah swt.:

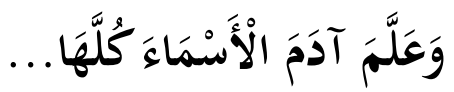

Terjemahnya:

“Dan Dia mengajarkan kepada Adam nama-nama (benda-benda) seluruhnya,... (QS. al-Baqarah [2]: 31) .

Setelah itu Allah swt. menguji kemampuan kapasitas pengetahuan nabi Adam a.s. dengan para malaikat dengan nama-nama (benda-benda), di dalam Firman Allah swt. disebutkan:

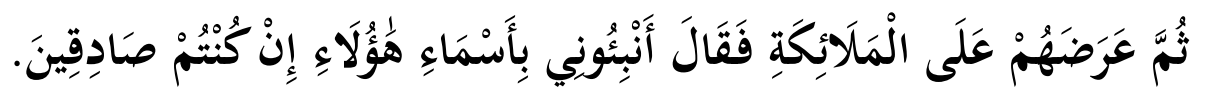

Terjemahnya:

“...kemudian mengemukakannya kepada para Malaikat, lalu berfirman: Sebutkanlah kepada-Ku nama benda-benda itu jika kalian mamang benar”. (QS. al-Baqarah [2]: 31).

Kemudian para malaikat menjawab sebagaimana Firman Allah swt.:

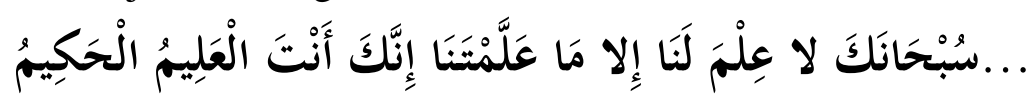

Terjemahnya:

"Maha Suci Engkau, tidak ada yang kami ketahui selain dari apa yang telah Engkau ajarkan kepada kami; sesungguhnya Engkaulah Yang Maha Mengetahui lagi Maha Bijaksana”. (QS. al-Baqarah [2]: 32). 


\section{Irfani}

ISSN 1907-0969 E ISSN 2442-8272

Volume 16 Nomor 1 Juni 2020

Halaman 69-81

http://journal.iaingorontalo.ac.id/index.php/ir

Allah swt. lalu berfirman:

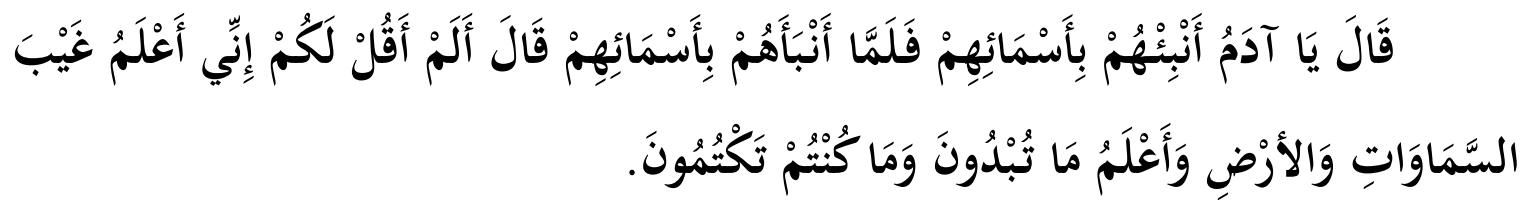

Terjemahnya:

"Allah berfirman: "Hai Adam, beritahukanlah kepada mereka nama-nama benda ini". Maka setelah diberitahukannya kepada mereka nama-nama benda itu, Allah berfirman: "Bukankah sudah Ku katakan kepadamu, bahwa sesungguhnya Aku mengetahui rahasia langit dan bumi dan mengetahui apa yang kamu lahirkan dan apa yang kamu sembunyikan?”. (QS. al-Baqarah [2]: 33).

Dari beberapa kutipan firman Allah swt. di atas, dapat dipahami bahwa proses pendidikan sudah terjadi dan dilakukan langsung oleh Allah swt. kepada manusia pertama yaitu Nabi Adam a.s sekaligus ditujukan kepada seluruh malaikat. Sebagai seorang calon khalifah di muka bumi, Nabi Adam a.s. harus dibekali dengan ilmu pengetahuan yang cukup agar dapat melaksanakan tugas kekhalifahannya dengan baik, dapat mengelola bumi agar dapat bermanfaat bagi kelangsungan hidup manusia sekaligus mendidik anak keturunannya agar menjadi manusia yang bertaqwa dan pewaris kekhalifahan yang handal serta tidak melakukan kerusakan di muka bumi.

\section{PENGERTIAN KARAKTER}

Secara bahasa, karakter berasal dari bahasa Yunani Charassein yang artinya mengukir. ${ }^{6}$ Melalui pengertian ini dapat dipahami bahwa sifat utama ukiran adalah melekat kuat di atas benda yang diukir. Tidak mudah usang ditelan oleh waktu atau terkena gesekan. Menghilang ukiran sama saja dengan menghilangkan benda yang diukir, merenda dengan gambar atau tulisan tinta yang hanya disatukan di atas permukaan benda. Karena itulah, sifatnya juga berbeda dengan ukiran, terutama dalam hal ketahanan dan kekuatannya dalam menghadapi tantangan waktu. ${ }^{7}$ Karakter disini dapat diartikan sebagai pola, baik itu pikiran, sikap, maupun tindakan, yang melekat pada diri seseorang dengan sangat kuat dan sangat sulit dihilangkan karena telah menyatu dari dirinya masih balita.

Karakter di sini merupakan nilai-nilai perilaku manusia yang berhubungan dengan Tuhan Yang Maha Esa, diri sendiri, sesama manusia, lingkungan. Karakter atau watak dapat

\footnotetext{
${ }^{6}$ Husna Nashihin, Pendidikan Karakter Berbasis Budaya Pesantren, (Semarang: Formaci, 2017), Cet. Ke- 1, hlm. 4

${ }^{7}$ Abdullah Munir, Pendidikan Karakter Membangun Karakter Anak Sejak Dari Rumah, (Yogyakarta: Pustaka Insan Madani, 2010), hlm. 2-3.
} 


\section{Irfani}

ISSN 1907-0969 E ISSN 2442-8272

Volume 16 Nomor 1 Juni 2020

Halaman 69-81

http://journal.iaingorontalo.ac.id/index.php/ir

dikembangkan oleh faktor-faktor pembawaan dan faktor-faktor eksogen seperti alam sekitar, pendidikan dan pengaruh dari luar pada umumnya. ${ }^{8}$

Karakter atau tabiat adalah "kualitas atau sifat yang tetap terus menerus dan kekal yang dapat dijadikan ciri untuk mengidentifikasikan seorang pribadi, suatu obyek atau kejadian". ${ }^{9}$ Menurut Netty Hartati ${ }^{10}$, karakter (character) adalah watak, perangai, sifat dasar yang khas, satu sifat atau kualitas yang tetap terus menerus dan kekal yang dapat dijadikan ciri untuk mengidentifikasi seorang pribadi. Ia disebabkan oleh bakat pembawaan dan sifatsifat hereditas sejak lahir dan sebagian disebabkan oleh pengaruh lingkungan. Ia berkemungkinan untuk dapat dididik. Elemen karakter terdiri atas dorongan-dorongan, insting, refleksi-refleksi, kebiasaan-kebiasaan, kecenderungan-kecenderungan, organ perasaan, sentimen, minat, kebajikan dan dosa, serta kemauan.

Lambat laun kata karakter memperoleh arti keseluruhan sifat-sifat individual manusia. Dalam hal ini, yang terangkum di dalamnya tidak hanya arah dari pada kehidupan perasaan dan hasrat saja, tetapi juga temperamen, bakat kemampuan dan seterusnya. Karakter hanya merupakan satu aspek dari kepribadian. Jadi, karakter adalah keseluruhan dari pada perasaan-perasaan dan hasrat yang telah terarah, seperti yang diorganisir oleh kehendak manusia Dengan demikian, karakter adalah sesuatu yang spesifik manusiawi. Binatang juga mempunyai perasaan dan hasrat, tetapi tak berkarakter. Karena binatang tidak berkehendak merdeka dan tidak menemukan sikap terhadap perasaan perasaan dan hasrat-hasrat. ${ }^{11}$

Karakter merupakan suatu keadaan jiwa. Keadaan ini menyebabkan jiwa bertindak tanpa pikir atau dipertimbangkan secara mendalam. Keadaan ini ada dua jenis. Yang pertama, alamiah dan bertolak dari watak. Misalnya pada orang yang gampang sekali marah karena hal-hal yang paling kecil. Yang kedua, tercipta melalui kebiasaan dan latihan. Pada mulanya keadaan ini terjadi karena dipertimbangkan dan difikirkan. Namun, kemudian melalui praktek terus menerus menjadi karakter. ${ }^{12}$

Dari pengertian-pengertian di atas dapat dipahami bahwa karakter merupakan perilaku, sifat, bawaan atau kebiasaan seseorang yang tertanam dari masa kecil hingga dewasa yang ia dapatkan dari lingkungannya. Salah satu contoh dari karakter itu sendiri bisa kita lihat pada pribahasa, kecil teranjak-anjak besar terbawa-bawa. Arti dari pribahasa tersebut adalah kebiasaan sejak kecil yang sudah menjadi hal yang biasa dan nantinya ketika dewasa sudah sulit untuk diubah. Baik dan buruk karakter seseorang bermula dari lingkungan itu sendiri,

\footnotetext{
${ }^{8}$ Soegarda Poerbakawatja dan Harahap, Ensiklopedi Pendidikan, (Jakarta: Gunung Agung, 1976), Cet. ke-3, hlm.161.

${ }_{9}^{9}$ J.P. Chaplin, Kamus Lengkap Psikologis, (Jakarta: Grafika Persada, 2001), hlm. 256.

${ }^{10}$ Netty Hartati, dkk., Islam dan Psikologi, (Jakarta: Raja Grafindo Persada, 2004), hlm. 137-138.

${ }^{11}$ Petrus Sardjonoprijo, Psikologi Kepribadian, (Jakarta: Rajawali, 1982), hlm. 89-90.

12 Abu Ali Akhmad Al-Miskawaih, Tahdhib Al-Akhlak, diterjemahkan oleh Helmi Hidayat dengan judul, Menuju Kesempurnaan Akhlak, (Bandung: Mizan, 1994), hlm.56.
} 


\section{Irfani}

ISSN 1907-0969 E ISSN 2442-8272

Volume 16 Nomor 1 Juni 2020

Halaman 69-81

http://journal.iaingorontalo.ac.id/index.php/ir

jika sewaktu kecil ditanamkan dengan kebiasaan yang baik maka karakter yang terbentuk ketika dewasa pun menjadi baik dan begitupun sebaliknya.

Setiap orang mempunyai karakter yang berbeda-beda dan sudah mendarah daging di dalam dirinya yang disebut dengan kebiasaan, kebiasaan baik menurut suatu kalangan, belum tentu baik bagi kalangan lainnya. Contoh sederhana dari hal tersebut dapat dilihat dalam suatu lingkungan. Di setiap lingkungan, karakter atau kebiasaan dibatasi dengan aturanaturan atau kebiasaan yang ada pada lingkungan lainnya, misalnya: kebiasaanya yang tidak pernah memakai jilbab dan ketika memasuki suatu kalangan yang mengharuskannya memakai jilbab atau kebiasaan yang sudah mendarah daging di dalam dirinya jika memasuki pada lingkungan yang mempunyai kebiasaan baik, maka dia diharuskan mengikuti kebiasaan baik di dalam lingkungan itu juga, jika tidak demikian, maka apa yang dilakukannya bertentangan dengan perilaku atau kebiasaan orang-orang yang ada di dalam lingkungan tersebut.

Karakter anak didik harus dibentuk sesuai dengan fitrahnya yang memungkinkannya untuk menguasai berbagai pengetahuan dan peradaban. Dengan memfungsikan fitrah itulah ia belajar dari lingkungan dan masyarakat dewasa yang mendirikan institusi pendidikan. Kondisi awal individu dan proses pendidikannya tersebut diisyaratkan oleh firman Allah swt.:

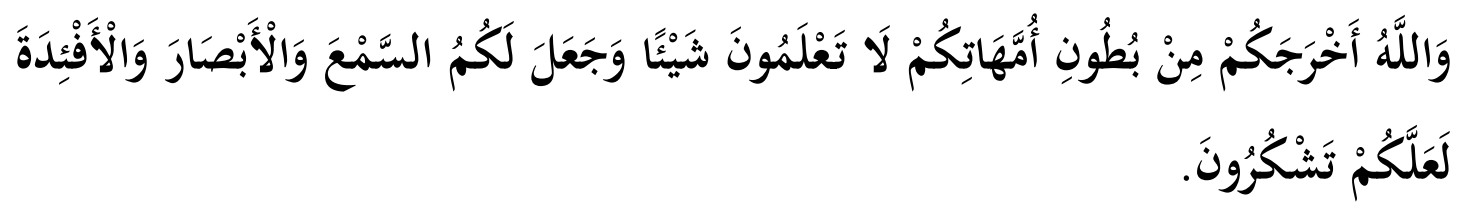

Terjemahnya:

"Dan Allah mengeluarkan kamu dari perut ibumu dalam Keadaan tidak mengetahui sesuatupun, dan Dia memberi kamu pendengaran, penglihatan dan hati, agar kamu bersyukur”. ( Q.S. al-Naḥl, [16]:78.)

Berdasarkan ayat di atas dapat dipahami bahwa membangun karakter yang kuat, serta menjadikan manusia yang berakhlak mulia dalam hal ini pendidikan mempunyai peran yang sangat penting, karena pendidikan merupakan proses pengembangan berbagai macam potensi yang ada dalam diri manusia agar dapat berkembang dengan baik dan bermanfaat bagi dirinya dan juga lingkungannya.

\section{PENGERTIAN AKHLAQ}

Secara etimologi kata akhlak berasal dari bahasa Arab khuluq yang jamaknya akhlaq. Menurut bahasa, akhlak adalah perangai, tabiat, dan agama. kata tersebut mengandung segisegi persesuaian dengan perkataan khalq yang berarti "kejadian", serta erat hubungannya dengan kata khaliq yang berarti "Pencipta" dan makhluq yang berarti "yang diciptakan". Dalam Kamus bahasa Indonesia, kata akhlak diartikan sebagai budi pekerti, watak, tabiat. Secara terminologi Al-Fairuzzabadi berkata, "ketahuilah, agama pada dasarnya adalah 


\section{Irfani}

ISSN 1907-0969 E ISSN 2442-8272

Volume 16 Nomor 1 Juni 2020

Halaman 69-81

http://journal.iaingorontalo.ac.id/index.php/ir

akhlak. Barangsiapa yang memiliki akhlak mulia, kualitas agamanya pun mulia. Agama diletakkan di atas empat landasan akhlak utama, yaitu kesabaran, memelihara diri, keberanian, dan keadilan. Ibn Al-Jauzi menjelaskan (w. 597 H) bahwa al-khuluq adalah etika yang dipilih seseorang. Dinamakan khuluq karna etika bagaikan khalqah (karakter) pada dirinya. Dengan demikian, khuluq adalah etika yang menjadi pilihan dan diusahakan seseorang. Adapun etika yang sudah menjadi tabiat bawaannya dinamakan al-khaym." 13

Dari pengertian akhlak di atas bahwa akhlak pada dasarnya adalah agama yakni agama Islam. Agamanya baik mencerminkan akhlaknya pun baik begitupun sebaliknya, karena akhlak atau agama berpegang teguh pada aturan-aturan yang sesuai dengan tunntunan Al-Qur'an dan Sunnah Nabi saw. untuk mencapai kebahagian dunia maupun akhirat. Akhlak mulia merupakan semua perilaku-perilaku baik yang diterima di setiap kalangan manapun, diterima di dalam semua aturan-aturan yang ada, baik di lingkungan itu sendiri maupun di lingkungan orang lain, dan tidak bertentangan dengan siapapun, serta tidak mempunyai batasan-batasan di dalam masyarakat karena akhlak adalah pengartian umum dari semua perilaku baik di dalam masyarakat maupun di dalam beragama.

Banyak yang menganggap bahwa akhlak sama halnya dengan karakter, benar jika dilihat dari sudut pengartiannya yakni "perilaku" akan tetapi nilai-nilai yang terkandung di dalamnya antara akhlak dan karakter mempunyai nilai-nilai yang berbeda. Nabi saw. diutus oleh Allah swt., selain untuk menyebarkan Agama Islam juga untuk menyempurnakan akhlaq yang mulia yang diharapkan bisa menjadi rahmatan lil 'ãlamin sebagai panutan yang baik, contoh yang baik, bukan saja untuk ummat Islam ke depannya akan tetapi untuk seluruh ummat manusia serta sebagai contoh kepada yang lain bahwa Agama Islam ini memiliki kepribadian yang mulia. Nabi saw. diturunkan oleh Allah swt. bukan untuk menyempurnakan akhlaq ummat karna ummat tidak ada akhlaq, akan tetapi menyempurnakan akhlaq yang belum sempurna dan kemudian disempurnakan menjadi akhlak mulia, sebagaimana sabda Nabi s.a.w.,

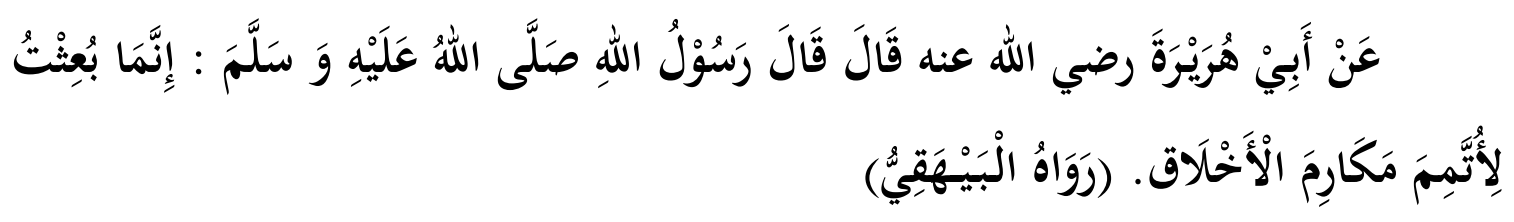

Terjemahnya:

"Dari Abu Hurairah Dia berkata, Rasulullah saw. bersabda: Sungguh aku diutus untuk menyempurnakan akhlak mulia”. (HR. Baihaqi). ${ }^{14}$

Di dalam sabda Nabi "menyempurnakan akhlak mulia", yakni akhlak itu pada hakikatnya adalah sifat umum perilaku baik, hanya saja diutusnya Nabi saw. untuk lebih

\footnotetext{
${ }^{13}$ Rosihon Anwar, Akhlak Tasawuf, (Bandung: Pustaka Setia, 2010), hlm. 11

${ }^{14}$ Ahmad bin al-Husain bin Ali binMusa Abubakar al-Baohaqi, Sunan al-Baihaqi al-Kubrā, Juz 10, (Mekkah al-Mukarramah: Maktabah Dār al-Bāz, 1994 M/1414 H), hlm. 191
} 


\section{Irfani}

ISSN 1907-0969 E ISSN 2442-8272

Volume 16 Nomor 1 Juni 2020

Halaman 69-81

http://journal.iaingorontalo.ac.id/index.php/ir

menjadikan akhlak itu menjadi lebih baik lagi dan menjadi mulia. Sehingga munculah kalimat "menyempurnakan" pada kalimat di atas karena akhlak merupakan perilaku yang berjalan sesuai dengan tuntunan atau pedoman penyempurna kehidupan kita yaitu Al-Qur'an dan al-Hadits. Menjadikan Rasulullah Muhammad SAW sebagai uswah hasanah dalam segala aspek kehidupannya itulah yang dimaksud ber-Islam secara kaffah (total).

\section{PERBEDAAN AKHLAQ DAN KARAKTER}

M.Abdullah Darraz mendefinisikan akhlak sesuatu kekuatan dalam kehendak yang mantap, sinergitas kekuatan dan kehendak melahirkan kecenderungan pada pemilihan pada yang baik (akhlak yang baik) atau pilihan pada yang buruk (akhlak yang buruk). ${ }^{15}$

Dari pengertian di atas dapat dipahami bahwa akhlak dalam pengertian "keadaan kejiwaan yang mendorong pemiliknya melakukan sesuatu perbuatan secara mudah, spontan, bahkan melakukannya secara serta merta." Perbuatan yang dilakukan dapat merupakan sesuatu yang baik, maka ketika itu dinilai memiliki akhlak yang baik (karimah/mulia/terpuji), dan dapat pula sebaliknya, maka ketika itu ia dinilai memiliki akhlak yang buruk (mazmumah/tercelah). Ukuran baik dan buruk didasarkan pada nilai-nilai yang dianut oleh masyarakat dimana yang bersangkutan berada. Kata akhlak berupakan bentuk jamak dari khuluk, mengisyaratkan cakupan yang luas. Secara garis besar dapat dikatakan bahwa akhlak merupakan aktivitas manusia yang mencakup hubungan manusia dengan Allah, dengan dirinya sendiri, dengan sesama manusia, dan dengan alam lingkungannya.

Dalam pendidikan akhlak ini, standar atau ukuran yang benar dan salah dalam menilai perbuatan yang muncul didasarkan kepada Al-Qur'an dan Sunnah sebagai sumber tertinggi ajaran Islam. Berdasarkan pemikiran di atas, maka pendidikan akhlak dapat dikatakan sebagai pendidikan karakter dalam wacana pendidikan Islam. ${ }^{16}$

Dalam hal internalisasi nilai-nilai baik dan mengabaikan atau menjauhi nilai-nilai yang buruk, maka pendidikan akhlak mempunyai orientasi yang sama dengan pendidikan karakter. Meskipun demikian, akhlak tidak dapat disamakan dengan karakter sebab akhlak bersumber dari ajaran yang diwahyukan Allah, sedangkan karakter bersumber pada hasil pemikiran manusia dan nilai kebaikan yang lahir dari kebiasaan masyarakat. Dengan demikian, nilai-nilai akhlak bersifat universal, abadi dan absolute, sedangkan karakter bersifat lokal, temporal, dan nisbi.

Selain itu, perilaku yang baik akan mendapatkan balasan pahala dan perilaku yang buruk akan mendapatkan dosa. Adanya pahala dan dosa menunjukkan bahwa keuntungan berperilaku baik akan dirasakan manusia baik ketika hidup di dunia maupun di akhirat, demikian pula sebaliknya. Janji pahala dan ancaman dosa merupakan faktor penting yang dapat menimbulkan motivasi yang sangat kuat kepada manusia untuk secara terus menerus mempertahankan akhlak yang baik. Adapun karakter tidak memiliki hal tersebut sehingga

\footnotetext{
${ }^{15}$ Erwin Yudi Prahara, Mareri Pendidikan Agama Islam, (Ponorogo: STAIN Po Press, 2009), hlm. 182

${ }^{16}$ Abudin Nata, Akhlak Tasawuf, (Jakarta: Rajawali Pers, 2002), Cet. Ke-4, hlm.12
} 


\section{Irfani}

ISSN 1907-0969 E ISSN 2442-8272

Volume 16 Nomor 1 Juni 2020

Halaman 69-81

http://journal.iaingorontalo.ac.id/index.php/ir

motivasi untuk tetap konsisten dengan karakter yang baik tidak sekuat mempertahankan akhlak yang baik.

Pendidikan karakter dan pendidikan akhlak sama-sama menekankan pentingnya keteladanan atau modeling. Oleh karena itu, dalam pendidikan akhlak para pendidik penganjur kebaikan diharuskan untuk dapat dan harus tampil sebagai tokoh teladan yang menjadi panutan peserta didik. Bahkan Al-Qur'an memberikan ancaman yang sangat serius yang sangat mengerikan kepada para pendidik atau penganjur kebaikan yang tidak mampu memberikan keteladanan. Adapun dalam pendidikan karakter meskipun ada keharusan bagi pendidik atau para penganjur untuk tampil sebagai tokoh teladan; namun tidak ditemukan adanya ancaman bagi mereka bila mereka tidak tampil sebagai tokoh teladan.

\section{PENDIDIKAN KARAKTER DENGAN NILAI-NILAI AKHLAQ}

Nilai akhlak sebagai suatu nilai atau sikap yang secara sadar dimiliki oleh manusia yang dilaksanakan secara sadar akan kebutuhan menjadi manusia yang utuh dan dapat hidup bersama dalam lingkup hubungannya dengan tuhan, sesama manusia, alam sekitar, dan diri sendiri. Proses pembentukan nilai tersebut dapat didasari pada pengetahuan mengapa nilai itu dilaksanakan. Pembelajaran nilai akhlak dapat meliputi langkah orientasi/informasi, pemberian contoh, latihan pembiasaan, umpan balik dan tindak lanjut. Langkah-langkah tersebut tidak harus selalu berurutan, melainkan berubah-ubah sesuai kebutuhan. ${ }^{17}$

Metode terbaik untuk mengajarkan nilai akhlak kepada anak-anak adalah dengan contoh atau teladan dari semua pihak, yaitu orang tua, guru, dan masyarakat. Ketika anakanak tidak memiliki hubungan dekat dengan orang tua mereka dan tidak mengenal nilai-nilai yang berlaku dalam keluarga, mereka akan menjadi lebih lemah dalam menghadapi tekanan dari teman-temannya. ${ }^{18}$

Pendidikan karakter dengan nilai-nilai akhlak memang sangat diperlukan oleh seorang muslim terlebih generasi muda. Seorang muslim seharusnya semenjak dini haruslah diajarkan tentang pendidikan nilai-nilai akhlak, supaya mereka kelak bisa mengemban tugas serta tanggung jawab dengan baik yang akan dihadapinya di masa yang akan datang, serta sebagai bahan acuan bagi para remaja muslim dalam bertingkah laku sehari-hari, supaya mereka dapat mencapai keselamatan serta kebahagiaan hidup di dunia sampai di akhirat kelak.

Pola penanaman nilai akhlak menjadi isu penting dalam dunia pendidikan. Hal ini berkaitan dengan fenomena moral yang terjadi di tengah-tengah masyarakat maupun dilingkungan pemerintah yang semakin meningkat dan beragam. Kriminalitas, ketidakadilan, korupsi, kekerasan pada anak, penyelenggaraan HAM, menjadi bukti bahwa telah terjadi krisis jati diri dan karakteristik pada bangsa Indonesia.

\footnotetext{
${ }^{17}$ Mansnur Musclish, Pendidikan Karakter (Menjawab Tantangan Multi Dimensional), (Jakarta: Bumi Aksara, 2011), Cet.ke-2, hlm.5

${ }_{18}$ Thomas Lickona, Educatting For Character Mendidik untuk Membentuk Karakter, (Jakarta: Bumi Aksara, 2012), Cet. Ke-5, hlm.54.
} 


\section{Irfani}

ISSN 1907-0969 E ISSN 2442-8272

Volume 16 Nomor 1 Juni 2020

Halaman 69-81

http://journal.iaingorontalo.ac.id/index.php/ir

Penanaman akhlak dalam mendidik karekter menjadi sebuah jawaban yang tepat atas permasalahan-permasalahan yang telah disebut di atas dan sekolah sebagai penyelenggara pendidikan diharap dapat menjadi tempat yang mampu mewujudkan misi dari pendidikan penanaman nilai akhlak tersebut.

\section{KESIMPULAN}

Dari telaah yang telah dilakukan, dapat ditarik beberapa kesimpulan, sebagai berikut: Secara umum, orientasi dari pendidikan akhlak dan pendidikan karakter memiliki kesamaan, yaitu berupaya menginternalisasi nilai-nilai baik dan mengabaikan atau menjauhi nilai-nilai buruk dalam kehidupan sehari-hari. Meskipun demikian, akhlak tidak dapat disamakan dengan karakter sebab akhlak bersumber dari ajaran yang diwahyukan Allah, sedangkan karakter bersumber pada hasil pemikiran manusia dan nilai kebaikan yang lahir dari kebiasaan masyarakat. Dengan demikian, nilai-nilai akhlak bersifat universal, abadi dan absolute, sedangkan karakter bersifat lokal, temporal, dan nisbi.

Dalam pendidikan karakter berbasis akhlak, standar ukuran yang benar dan yang salah dalam menilai suatu perbuatan didasarkan kepada Al-Qur'an dan Sunnah sebagai sumber tertinggi ajaran Islam, dan menginternalisasikan nilai-nilai yang ada di dalamnya dalam seluruh aspek kehidupan manusia, khususnya pada aspek pendidikan. Sehingga dapat dikatakan bahwa pendidikan karakter berbasis akhlak merupakan sebuah bentuk pendidikan karakter dalam wacana pendidikan Islam. Pembelajaran nilai akhlak dapat meliputi langkah orientasi/informasi, pemberian contoh, latihan pembiasaan, umpan balik dan tindak lanjut. Langkah-langkah tersebut tidak harus selalu berurutan, melainkan berubah-ubah sesuai kebutuhan. ${ }^{19}$

Metode terbaik untuk mengajarkan nilai akhlak kepada anak-anak adalah dengan contoh atau teladan dari semua pihak, yaitu orang tua, guru, dan masyarakat. Ketika anakanak tidak memiliki hubungan dekat dengan orang tua mereka dan tidak mengenal nilai-nilai yang berlaku dalam keluarga, mereka akan menjadi lebih lemah dalam menghadapi tekanan dari teman-temannya. ${ }^{20}$

\section{DAFTAR PUSTAKA}

Al-Baihaqi, Ahmad bin al-Husain bin Ali bin Musa Abu bakar. 1994 M/ 1414 H. Sunan alBaihaqi al-Kubrā, Juz 10. Mekkah al-Mukarramah: Maktabah Dār al-Bāz.

Al-Miskawaih, Abu Ali Akhmad. 1994. Tahdhib Al-Akhlak, diterjemahkan oleh Helmi Hidayat dengan judul, Menuju Kesempurnaan Akhlak. Bandung: Mizan.

Anwar, Rosihon. 2010. Akhlak Tasawuf. Bandung: Pustaka Setia.

\footnotetext{
${ }^{19}$ Mansnur Musclish, Pendidikan Karakter (Menjawab Tantangan Multi Dimensional), (Jakarta: Bumi Aksara, 2011), Cet.ke-2, hlm.5

${ }^{20}$ Thomas Lickona, Educatting For Character Mendidik untuk Membentuk Karakter, (Jakarta: Bumi Aksara, 2012), Cet. Ke-5, hlm.54.
} 


\section{Irfani}

ISSN 1907-0969 E ISSN 2442-8272

Volume 16 Nomor 1 Juni 2020

Halaman 69-81

http://journal.iaingorontalo.ac.id/index.php/ir

Chaplin, J.P. 2001. Kamus Lengkap Psikologis. Jakarta: Grafika Persada.

Chomaidi dan Salamah. 2018. Pendidikan dan Pengajaran Strategi Pembelajaran Sekolah. Jakarta: Grasindo.

Darmadi, Hamid. 2019. Pengantar Pendidikan Era Globalisasi. Banten: An1mage.

Hartati, Netty.dkk. 2004. Islam dan Psikologi. Jakarta: Raja Grafindo Persada.

Haryanti, Nik. 2014. Ilmu Pendidikan Islam. Malang: Gunung Samudra. Cet. Ke-1.

Hasanah, Uswatun. 2016. Model-model Pendidikan Karekter di Sekolah. Al-Tadzkiyyah: Jurnal Pendidikan Islam. Vol. 7.

Husna Nashihin. 2017. Pendidikan Karakter Berbasis Budaya Pesantren. Semarang: Formaci. Cet. Ke- 1.

Munir, Abdullah. 2010. Pendidikan Karakter Membangun Karakter Anak Sejak Dari Rumah. Yogyakarta: Pustaka Insan Madani.

Musclish, Mansnur. 2011. Pendidikan Karakter (Menjawab Tantangan Multi Dimensional). Jakarta: Bumi Aksara.

Nata, Abudin. 2002. Akhlak Tasawuf. Jakarta: Rajawali Pers.

Neolaka, Amos. dan Grace Amialia A. Neolaka. 2017. Landasan Pendidikan Dasar Pengenalan Diri Sendiri Menuju Perubahan Hidup. Depok: Kencana. Cet. Ke-1.

Poerbakawatja, Soegarda., dan Harahap.1976. Ensiklopedi Pendidikan. Jakarta: Gunung Agung.

Prahara, Erwin Yudi. 2009. Mareri Pendidikan Agama Islam. Ponorogo: STAIN Po Press.

Sardjonoprijo, Petrus. 1982. Psikologi Kepribadian. Jakarta: Rajawali. 